\title{
Degradation of Plastics in Seawater in Laboratory
}

\author{
Juan C. Alvarez-Zeferino1, Margarita Beltrán-Villavicencio1, Alethia Vázquez-Morillas',2 \\ ${ }^{1}$ Universidad Autónoma Metropolitana, Unidad Azcapotzalco, San Pablo 180, Col. Reynosa Tamaulipas, Del. \\ Azcapotzalco, México City, México \\ ${ }^{2}$ Sociedad Mexicana de Ciencia y Tecnología Aplicada a Residuos Sólidos, A.C., Mexico City, México \\ Email: alethia@correo.azc.uam.mx,jucaf@correo.azc.uam.mx,mbv@correo.azc.uam.mx
}

Received 1 October 2015; accepted 2 November 2015; published 6 November 2015

Copyright (C) 2015 by authors and Scientific Research Publishing Inc.

This work is licensed under the Creative Commons Attribution International License (CC BY). http://creativecommons.org/licenses/by/4.0/

(c) (7) Open Access

\begin{abstract}
Degradable plastics are used as a way to decrease the environmental impact of these materials when they become waste. However, they can reach natural ecosystems due to littering and bad management. This research assesses the performance of oxodegradable and compostable plastics on marine environments through a respirometric lab test. Probes of the plastics, with and without previous simulated weathering, were put in contact for 48 days with a marine inoculum, in a system that guarantees continuous aeration and capture of the produced $\mathrm{CO}_{2}$. After the test, the samples were also assessed in terms of their loss of mechanical properties. The compostable plastic exhibited the higher degree of mineralization $(10 \%)$, while there was no difference between the polyolefins $(2.06 \%-2.78 \%)$, with or without presence of pro-oxidants or previous abiotic degradation. On the other hand, exposition to UV light promoted a higher loss of elongation at break in the oxodegradables plastic ( $>68 \%$ ). The results show that the studied plastics achieve very low biodegradation rates while presenting a higher rate of loss of physical integrity. This combination of phenomena could lead to their fragmentation before significant biodegradation can occur. The risk of microplastics formation must be prevented by avoiding the presence of the materials in marine environments, even if they have shown suitability for some waste management scenarios.
\end{abstract}

\section{Keywords}

Mineralization, Oxodegradable, Marine Environment, Polylactic Acid

\section{Introduction}

The plastics are nowadays essential materials; they are used in different productive sectors, like automotive, medical, electronics, construction, and food industry, among others [1] [2]. Their use has increased continuously

How to cite this paper: Alvarez-Zeferino, J.C., Beltrán-Villavicencio, M. and Vázquez-Morillas, A. (2015) Degradation of Plastics in Seawater in Laboratory. Open Journal of Polymer Chemistry, 5, 55-62. 
due to their low cost and attractive properties, such as a high resistance, versatility and low weight. However, when the plastic items are considered as wastes and their disposal is inappropriate, they become a serious problem due to their low degradability in the environment [3]. Marine environment has been seriously affected by discarded plastics.

The plastic wastes that arrive to these environments can cause damage to marine species. Different affectations in marine animals have been reported: ingestion causing eating disorders [4], entanglement and induced asphyxiation [5] or hurt due to the form of the waste. Presence or damage due to plastics has been reported for mammals [6], turtles [7], and seabirds [4], among other species.

Different types of degradable have been proposed as an alternative to lessen the environmental impacts of plastic waste. Compostable and oxodegradable plastics are two of the main types of plastics available in the market. Oxodegradable plastics are made of conventional plastics amended with additives that contain pro-oxidants like Co and Mn salts. They are an alternative for the increased degradability of plastic like polyethylene and polystyrene [8]. The pro-oxidants activate through UV radiation or temperature, they form free radicals that attack the polymer chain, causing the transformation of molecules of high molecular weight to low molecular weight [9]. It is expected that microorganisms, producing the mineralization of the material by its conversion to $\mathrm{CO}_{2}$, will metabolize the resulting oligomers and lower molecular weight compounds.

On the other hand, compostable plastics are specifically designed to biodegrade in composting conditions (thermofilic temperature, $50 \%$ - 60\% moisture, presence of microorganisms). One of this plastics is Ecovio ${ }^{\circledR}$, is a compostable plastic that is manufactured by polylactic acid (PLA) and Ecoflex ${ }^{\circledR}$, the last is an aliphatic-aromatic copolyesters compound of terephthalic acid, adipic acid and butanediol [10].

Although compostable and oxodegradable plastics have shown significant levels of degradation in aerobic conditions [11]-[13], there is a lack of knowledge regarding their biodegradation in marine environments. Degradation of plastics can be assessed by their direct exposure to marine conditions, in situ. However, this kind of test usually involves high costs and requires specific monitoring procedures to prevent loss of samples, and is not specific to test for biodegradation. Because of that, standards have been developed to evaluate the biodegradation of plastics in marine conditions at laboratory, the ASTM D6691-09 establish a "Standard Test Method for Determining Aerobic Biodegradation of Plastic Materials in the Marine Environment by a Defined Microbial consortium or Natural Sea Water Inoculum” [14].

In this project, we evaluate the biodegradation and loss of mechanical properties for conventional, oxodegradable and compostable plastics, following the standard ASTM D6691-09. This system allows reproducing marine conditions in a more controlled environment. Our test also assesses the effect of previous abiotic degradation due to simulated weathering in the samples.

\section{Materials and Methods}

Biodegradation of plastics in natural seawater in laboratory was assessed according to the method ASTMD6691-2009. It allows evaluating the degree of aerobic biodegradation of plastic materials exposed to a marine microbial consortium from seawater. The test was performed in four steps: 1) Selection and preparation of plastic samples; 2) Obtaining of a seawater sample, that is amended with inorganic nutrients; 3) Exposition of materials to the inoculum; 4) Measurement of the $\mathrm{CO}_{2}$ produced as a function of time, using a respirometric system; 5) Assessment of the degree of biodegradability. After this test, degradation of plastics (biotic + abiotic) was evaluated by the measurement of their loss in elongation at break.

\subsection{Tested Materials}

Three types of plastics were evaluated: low-density polyethylene with and without pro-oxidant additive (OXOLDPE and LDPE, respectively), and the compostable plastic Ecovio ${ }^{\circledR}$. Both polyolefins were supplied by Artes Gráficas Unidas. S. A. de C. V. AGUSA (Mexico), who used the $\mathrm{d} 2 \mathrm{w}^{\circledR}$ pro-oxidant additive from Plásticos Degradables S.A. de C.V. (México), subsidiary of Symphony Environmental. The compostable plastic was provided by BASF-México. It is composed of an aliphatic-aromatic mixture of the copolyester Ecoflex ${ }^{\circledR}$ (also produced by BASF) and polylactic acid (PLA). All the plastics were cut into $150 \times 10 \mathrm{~mm}$ probes, and half of each type of plastic was abiotically oxidized in a previously described weathering chamber built at the university [15], in order to simulate the degradation produced by use, UV radiation and temperature. In the chamber, the materials were exposed to $50^{\circ} \mathrm{C}, 80 \%$ relative humidity and a radiation interval 300 - 460 nm during 216 hours, 
the time needed for the OXOLDPE to decrease its elongation at break to values near to $100 \%$, because of the abiotic degradation process. First, confirm that you have the correct template for your paper size. This template has been tailored for output on the custom paper size $(21 \mathrm{~cm} \times 28.5 \mathrm{~cm})$.

\subsection{Preparation of Inoculum}

The seawater used in this study was obtained from the Barra Norte beach in Tuxpan (Veracruz, Mexico, Figure 1). The seawater was transported in sterilized containers to the laboratory, where it arrived 4 hours after sampling. It had a pH of $7.85 \pm 0.07$ and salinity of $50.5 \pm 1.2 \mathrm{mS} / \mathrm{cm}$. The reactors used to assess degradation had a volume $2 \mathrm{~L}$, and were filled with $1.2 \mathrm{~L}$ of seawater amended with inorganic nutrients $\left(0.5 \mathrm{~g} / \mathrm{L} \mathrm{of} \mathrm{NH}_{4} \mathrm{Cl}\right.$ and, 0.1 $\mathrm{g} / \mathrm{L}$ of $\left.\mathrm{KH}_{2}(\mathrm{PO})_{4}\right)$ and was incubated at $30^{\circ} \mathrm{C} \pm 1^{\circ} \mathrm{C}$ for 48 days. Air was continuously flown into the reactors during the respirometric test.

\subsection{Aeration System Used to Assess Biodegradation}

The corresponding plastics were introduced into the reactors containing amended seawater. The mass of each plastic is shown in Table 1. Cellulose was used as a positive control, and reactors containing only amended seawater were used as blanks. Three replicates were setup for each plastic and control (Table 2). They were subsequently connected to a respirometric system (Figure 2), which included a continuous flow or $\mathrm{CO}_{2}$-free, saturated air to guarantee aerobic conditions and a series of traps to capture the $\mathrm{CO}_{2}$ produced by the plastic degradation.

Solutions of $\mathrm{NaOH}(0.25 \mathrm{~N})$ were used as traps for $\mathrm{CO}_{2}$. They were subsequently titrated with $0.5 \mathrm{~N} \mathrm{HCl}$ solution twice a week. Biodegradation of samples was determined in terms of mineralization (\%), with Equation (1):

$$
\text { Mineralitation }(\%)=\frac{C_{\text {test }}-C_{\text {blank }}}{C_{i}}
$$

where $C_{\text {test }}$ is the mean of the amount of $\mathrm{CO}_{2}$ produced in the replicates for each plastic (mg), $C_{\text {blank }}$ is the mean $\mathrm{CO}_{2}$ production in the blanks (inoculum only; $\mathrm{mg}$ ) and $C_{i}$ was the total amount of polymer-C added to the test reactors (mg).

\subsection{Assessment of Degradation by Tensile Tests}

The tensile elongation at break was assessed as an indicator of degradation (abiotic + biotic), as done previously

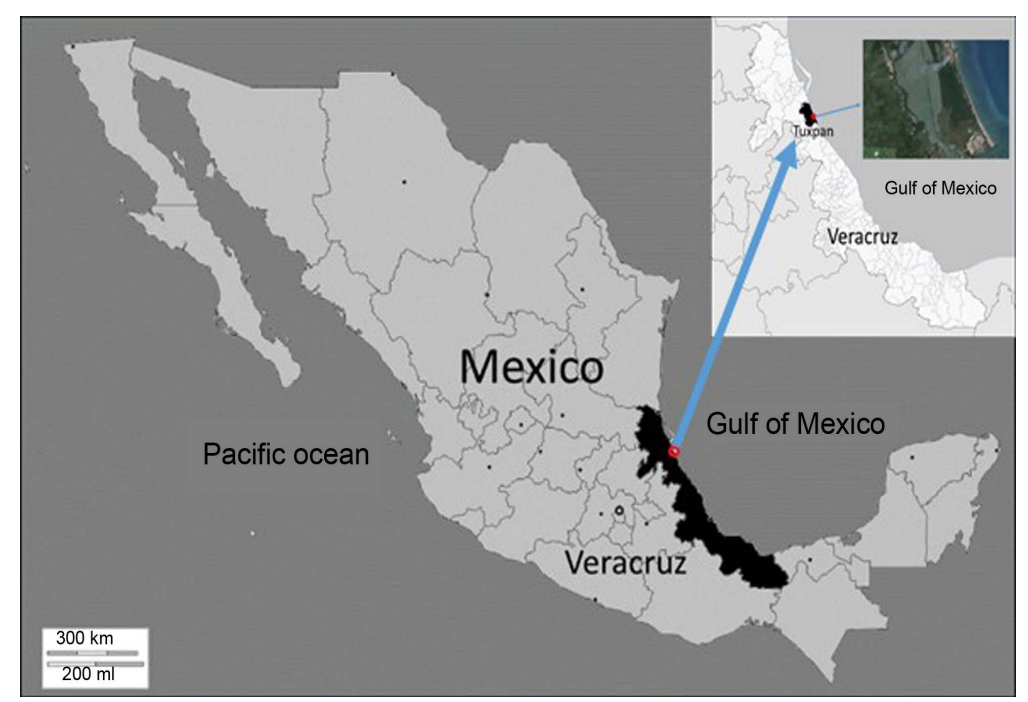

Figure 1. Location of the beach selected for sampling of seawater. Tuxpan Beach, Veracruz Mexico. 


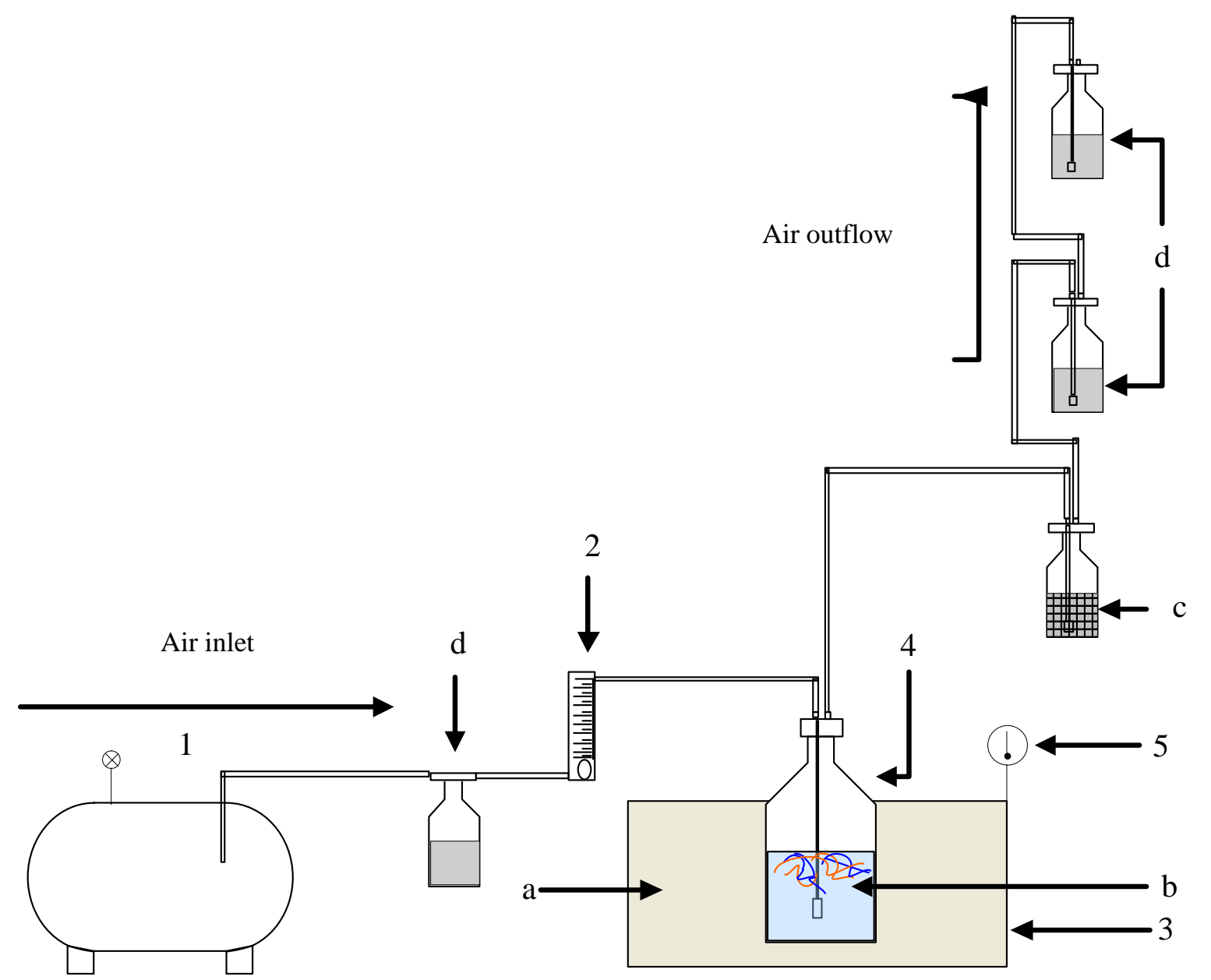

Figure 2. Respirometric system. (a) Distilled water, (b) Seawater with inorganic nutrients and plastics, (c) Silica trap, (d) NaOH solution trap, 1) Compressor, 2) Flow regulator, 3) Water bath, 4) Reactor, 5) Thermometer.

Table 1. Mass of each plastic utilized in the test.

\begin{tabular}{cc}
\hline Treatments & Sample mass (mg) \\
\hline Cellulose & 1000 \\
LDPE & 807 \\
LDPE-O & 807 \\
Ecovio $^{\circledR}$ & 810 \\
Ecovio $^{\circledR}$-O & 810 \\
OXO-LDPE & 926 \\
OXO-LDPE-O & 926 \\
\hline
\end{tabular}

Table 2. Types of plastic used in the experiment, with and without oxidation.

\begin{tabular}{ccc}
\hline Plastic & With oxidation & Without oxidation \\
\hline LDPE & 3 & 3 \\
OXOLDPE & 3 & 3 \\
Ecovio $^{\circledR}$ & 3 & 3 \\
Total & 9 & 9 \\
\hline
\end{tabular}


[16] [17]. It was measured based on the standard ASTM D882 [18]. The machine used was a Lloyd LFPlus (AMETEK Lloyd Instrument Ltd. UK). The testing speed was maintained at $300 \mathrm{~mm} / \mathrm{min}$ and the grip-to-grip separation was $30 \mathrm{~mm}$. Conditioning and testing were performed at standard atmospheric conditions $\left(24^{\circ} \mathrm{C} \pm\right.$ $1{ }^{\circ} \mathrm{C}$ and $50 \% \pm 10 \% \mathrm{RH}$ ). The residual elongation at break (\%REB) was determined using Equation (2).

$$
\text { Residual elongation at } \operatorname{break}(\%)=\frac{\text { Initial value }- \text { Final value }}{\text { Initial value }} * 100
$$

The data obtained from tensile tests underwent an analysis of variance (ANOVA) and a Tukey's multiple range test (MRT), both with 95\% significance. The biodegradation stage was not included in the statistical analysis because it did not have a normal distribution.

\section{Results and Discussion}

\subsection{Biodegradation}

After 48 days of experimentation, the cellulose reactors showed $68.3 \%$ of mineralization. This value is consistent with others reported before in composting conditions: $80 \%$ in 90 days and 100\% in 317 days [19] [20], and it can be considered as a measurement of the good performance of the respirometric system. The two polyolefins, with and without pro-oxidant additive or previous degradation process, did not show a significant difference in mineralization, which ranged from $2.06 \%$ to $2.78 \%$. Ecovio ${ }^{\circledR}$, on the other hand, achieved $10.11 \%$ and $10.38 \%$ for oxidized and no-oxidized samples, respectively (Figure 3). There are no similar researches, which allow comparing of these results; however, biodegradation of these plastics in other environments has been reported previously. Mineralization values from $2 \%$ to $2.5 \%$ and $7 \%$ to $10 \%$ were reported for LDPE and OXOLDPE, after incubation in soil at $45^{\circ} \mathrm{C}$, during 90 days [21]. In a composting process inoculated with Rhodococcus rhodochrous LDPE reached 9\% of mineralization, while OXOLDPE achieved 16\%, after 317 and 352 days of degradation [20]. As it can be observed, the low degree of mineralization achieved for LDPE and OXOLDPE in our experiment is consistent with reported values.

\subsection{Degradation by Elongation at Break}

Statistical analysis showed significant differences $(\mathrm{p}<0.05)$ between the different plastics. The MRT analysis yields five homogeneity groups, where LDPE and previously oxidized LDPE (LDPE-O) had the lower \%REB, with $9.3 \%$ and $17.1 \%$, respectively. OXO-LDPE achieved a $29.11 \%$, while Ecovio ${ }^{\circledR}$, with and without oxidation, showed a similar behavior. The highest loss of elongation was found for previously oxidized OXO-LDPE (OXO-LDPE-O), which decreased its mechanical resistance in 67.85\% during the test (Figure 4).

Biodegradation rates measured by respirometric tests cannot be directly compared to the loss of elongation at break, which is a result of both, biotic and abiotic factors. In this research, Ecovio ${ }^{\circledR}$ achieved the highest degree of biodegradation, while previously oxidized OXOLDPE had the higher loss of elongation at break. Degradation on natural marine environments is a complex multifactorial process that could be affected by the types and amount of living organisms, presence of soluble salts, temperature, dissolved oxygen, UV radiation and by the movement of the water. There is not available information about the degradation of plastics by sea salts, although it is known that soluble marine salts cause alterations on physical and chemical properties of anticorrosive paints and concrete [22] [23]. It also has been reported that microorganisms such as bacteria and fungi can form a biofilm on plastics, producing enzymes that promote the change of physicochemical properties of the plastic [24] [25].

Previous oxidation by UV and temperature clearly promoted further degradation in the polyolefins, which consistently showed higher values of \%REB, compared to those that had no treatment. It is known that for this plastics once light begins degradation, the process tend to continue [26], favoring subsequent biotic and abiotic processes. While is common for polyolefins to begin their degradation by this kind of chemical interaction, Ecovio ${ }^{\circledR}$ contains PLA, which begins its degradation by non enzymatic hydrolysis [27]. Previous exposition to UV light did not affect its degradation. In terms of percent of mineralization, compostable plastic presented faster than both polyolefins mineralization. The values obtained for all the plastics are similar to those reported before for direct exposure on marine environments [28]; this shows that the respirometric system used in this experiment is a useful tool to an easier and cheaper screening of the performance of this plastics. 


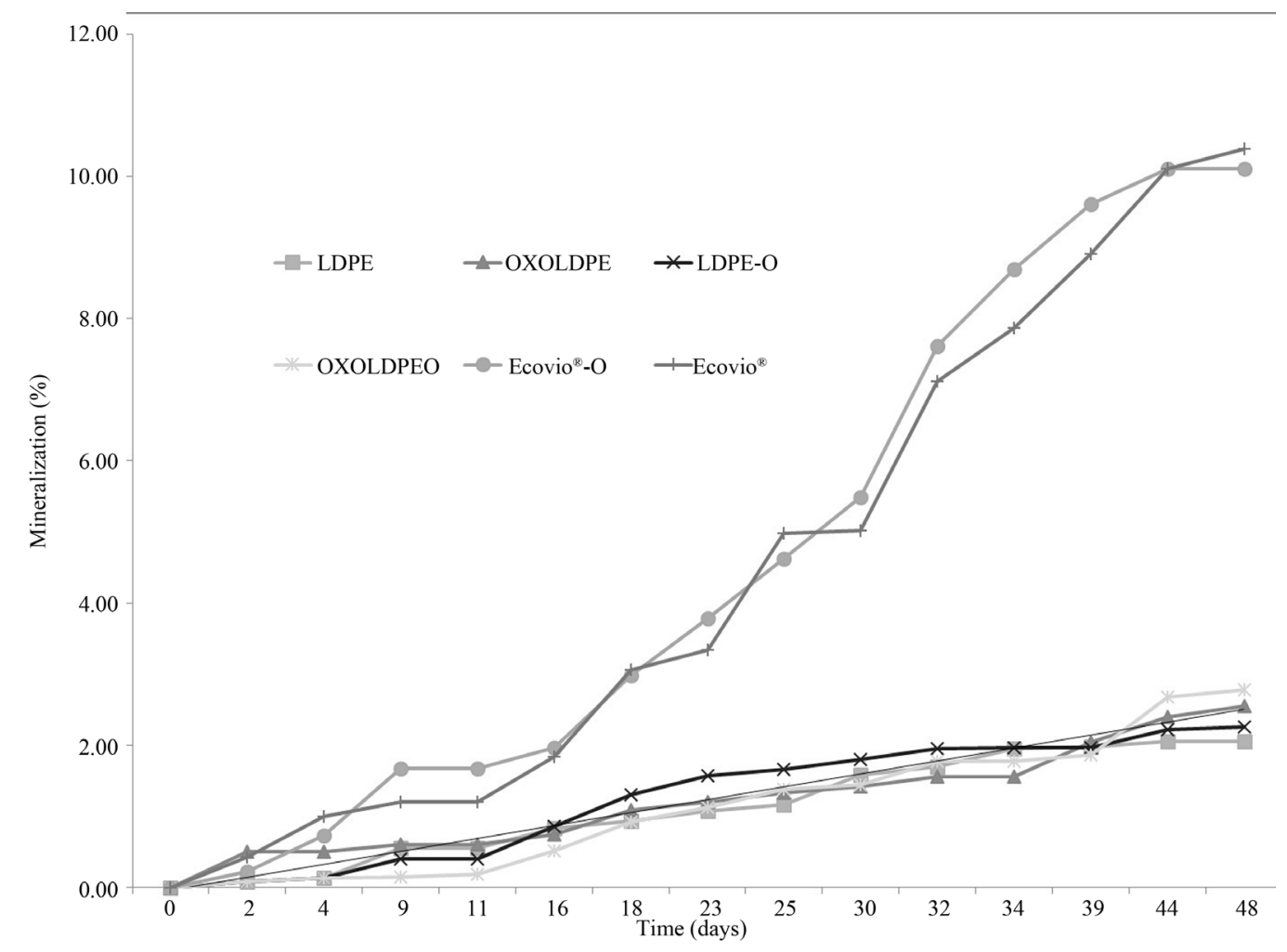

Figure 3. Mineralization of plastics produced by biodegradation in natural seawater.

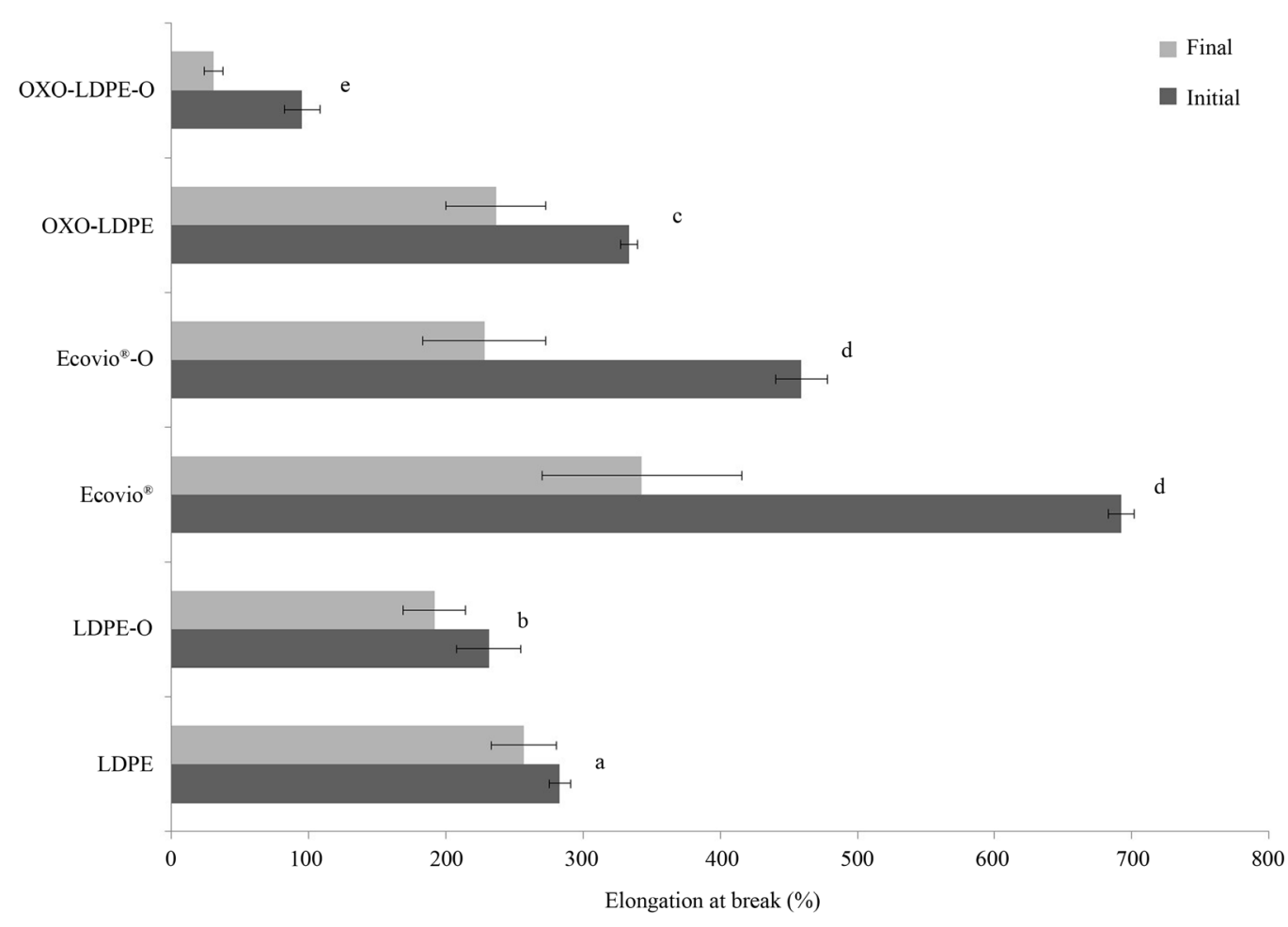

Figure 4. Elongation at break (\%) during the exposure in laboratory marine conditions. Groups Significantly different from ANOVA and MRT test are indicated with different letters. Five homogeneity groups are distinguished. 
It is relevant to consider that loss of physical integrity, which is related to the loss in elongation at break, cannot be considered inherently beneficial. If the fragmentation process occurs at higher rates than the biodegradation process, microplastics could be produced. The presence of these small particles of plastics in the sea has been widely reported in literature, as well as their transport through the food chain [29] [30].

\section{Conclusions}

Degradable plastics have been presented as an alternative to solve the problems generated by plastic waste. They are usually designed to degrade in the conditions of waste management, mainly in composting conditions. However, the new materials can reach natural environments due to littering, inefficient waste management programs or even when being disposed anywhere by people that consider them degradable in any conditions.

In the present study, we found very low degree of marine biodegradation, in lab conditions, for a compostable plastic, and almost none for the studied polyolefins, independently of the presence of a pro-oxidant additive or previous treatment in a weathering chamber. However, all the plastics showed some loss of their mechanical properties, as shown for the decrease in elongation at break. In this case, the presence of the additive and the UV abiotic oxidation clearly induced further degradation when the plastics were in contact with the marine inoculum.

Although the results cannot be extrapolated to real degradation in marine environments, they clearly show that complete biodegradation of plastics — even if they are labelled as degradable — cannot be guaranteed before other degradation processes take place. To prevent undesirable effects of these materials, such as the formation of microplastics, their users must be conscious of their properties and limitations, and use them in conditions consistent with them.

\section{References}

[1] Thompson, R.C., Swan, S.H., Moore, C.J. and vom Saal, F.S. (2009) Our Plastic Age. Philosophical Transactions of the Royal Society B: Biological Sciences, 364, 1973-1976. http://dx.doi.org/10.1098/rstb.2009.0054

[2] Scott, G. (1999) Polymers and the Environment. Royal Society of Chemistry, London.

[3] Ojeda, T.F.M., Dalmolin, E., Forte, M.M.C., Jacques, R.J.S., Bento, F.M. and Camargo, F.A.O. (2009) Abiotic and Biotic Degradation of Oxo-Biodegradable Polyethylenes. Polymer Degradation and Stability, 94, 965-970. http://dx.doi.org/10.1016/j.polymdegradstab.2009.03.011

[4] Codina-García, M., Militão, T., Moreno, J. and González-Solís, J. (2013) Plastic Debris in Mediterranean Seabirds. Marine Pollution Bulletin, 77, 220-226. http://dx.doi.org/10.1016/j.marpolbul.2013.10.002

[5] Waluda, C.M. and Staniland, I.J. (2013) Entanglement of Antarctic fur Seals at Bird Island, South Georgia. Marine Pollution Bulletin, 74, 244-252. http://dx.doi.org/10.1016/j.marpolbul.2013.06.050

[6] Williams, R., Ashe, E. and O’Hara, P.D. (2011) Marine Mammals and Debris in Coastal Waters of British Columbia, Canada. Marine Pollution Bulletin., 62, 1303-1316. http://dx.doi.org/10.1016/j.marpolbul.2011.02.029

[7] Lazar, B. and Gračan, R. (2011) Ingestion of Marine Debris by Loggerhead Sea Turtles, Caretta caretta, in the Adriatic Sea. Marine Pollution Bulletin, 62, 43-47. http://dx.doi.org/10.1016/j.marpolbul.2010.09.013

[8] Ojeda, T., Freitas, A., Dalmolin, E., Pizzol, M.D., Vignol, L., Melnik, J., et al. (2009) Abiotic and Biotic Degradation of Oxo-Biodegradable Foamed Polystyrene. Polymer Degradation and Stability, 94, 2128-2133. http://dx.doi.org/10.1016/j.polymdegradstab.2009.09.012

[9] Jakubowicz, I. and Enebro, J. (2012) Effects of Reprocessing of Oxobiodegradable and Non-Degradable Polyethylene on the Durability of Recycled Materials. Polymer Degradation and Stability, 97, 316-321. http://dx.doi.org/10.1016/j.polymdegradstab.2011.12.011

[10] Witt, U., Einig, T., Yamamoto, M., Kleeberg, I., Deckwer, W.D. and Müller, R.J. (2001) Biodegradation of AliphaticAromatic Copolyesters: Evaluation of the Final Biodegradability and Ecotoxicological Impact of Degradation Intermediates. Chemosphere, 44, 289-299. http://dx.doi.org/10.1016/S0045-6535(00)00162-4

[11] Chiellini, E., Corti, A. and D’Antone, S. (2007) Oxo-Biodegradable Full Carbon Backbone Polymers Biodegradation Behaviour of Thermally Oxidized Polyethyleno in an Aqueous Mediem. Polymer Degradation and Stability, 92, 13781383. http://dx.doi.org/10.1016/j.polymdegradstab.2007.03.007

[12] Corti, A., Muniyasamy, S., Vitali, M., Imam, S.H. and Chiellini, E. (2010) Oxidation and Biodegradation of Polyethylene Films Containing Pro-Oxidant Additives: Synergistic Effects of Sunlight Exposure, Thermal Aging and Fungal Biodegradation. Polymer Degradation and Stability, 95, 1106-1114.

http://dx.doi.org/10.1016/j.polymdegradstab.2010.02.018 
[13] Li, F., Wang, S., Liu, W. and Chen, G. (2008) Progress on Biodegradation of Polylactic Acid-A Review. Acta microbiologica Sinica, 48, 262-268.

[14] ASTM-D6691 (2009) Standard Test Method for Determining Aerobic Biodegradation of Plastic Materials in the Marine Environmental by a Defined Microbial Consortium or Natural Sea Water Inoculum.

[15] Cruz-Navarro, D.S., Espinosa-Valdemar, R.M., Beltrán-Villavicencio, M., Vázquez-Morillas, A. and Velasco-Pérez, M. (2014) Degradation of Oxo-Degradable-Polyethylene and Polylactic Acid Films Embodied in the Substrate of the Edible Fungus Pleurotus ostreatus. Natural Resources, 5, 949-957.

[16] Jiang, L., Wolcott, M.P. and Zhang, J. (2006) Study of Biodegradable Polylactide/Poly(butylene adipate-co-terephthalate) Blends. Biomacromolecules, 7, 199-207. http://dx.doi.org/10.1021/bm050581q

[17] Benítez, A., Sánchez, J.J., Arnal, M.L., Müller, A.J., Rodríguez, O. and Morales, G. (2013) Abiotic Degradation of LDPE and LLDPE Formulated with a Pro-Oxidant Additive. Polymer Degradation and Stability, 98, 490-501. http://dx.doi.org/10.1016/j.polymdegradstab.2012.12.011

[18] ASTM International (1997) ASTM D 882-97. Método de prueba estandar para película plástica delgada.

[19] Yashchuk, O., Portillo, F.S. and Hermida, E.B. (2012) Degradation of Polyethylene Film Samples Containing OxoDegradable Additives. Procedia Materials Science, 1, 439-445. http://dx.doi.org/10.1016/j.mspro.2012.06.059

[20] Fontanella, S., Bonhomme, S., Koutny, M., Husarova, L., Brusson, J.-M., Courdavault, J.-P., et al. (2010) Comparison of the Biodegradability of Various Polyethylene Films Containing Pro-Oxidant Additives. Polymer Degradation and Stability, 95, 1011-1021. http://dx.doi.org/10.1016/j.polymdegradstab.2010.03.009

[21] Abrusci, C., Pablos, J.L., Corrales, T., López-Marín, J., Marín, I. and Catalina, F. (2011) Biodegradation of Photo-Degraded Mulching Films Based on Polyethylenes and Stearates of Calcium and Iron as Pro-Oxidant Additives. International Biodeterioration \& Biodegradation, 65, 451-459. http://dx.doi.org/10.1016/j.ibiod.2010.10.012

[22] Morcillo, M. (1999) Soluble Salts: Their Effect on Premature Degradation of Anticorrosive Paints. Progress in Organic Coatings, 36, 137-147. http://dx.doi.org/10.1016/S0300-9440(99)00036-3

[23] Barone, G., Mazzoleni, P., Pappalardo, G. and Raneri, S. (2015) Microtextural and Microstructural Influence on the Changes of Physical and Mechanical Proprieties Related to Salts Crystallization Weathering in Natural Building Stones. The Example of Sabucina Stone (Sicily). Construction and Building Materials, 95, 355-365. http://dx.doi.org/10.1016/j.conbuildmat.2015.07.131

[24] Lobelle, D. and Cunliffe, M. (2011) Early Microbial Biofilm Formation on Marine Plastic Debris. Marine Pollution Bulletin, 62, 197-200. http://dx.doi.org/10.1016/j.marpolbul.2010.10.013

[25] Sudhakar, M., Trishul, A., Doble, M., Kumar, K.S., Jahan, S.S., Inbakandan, D., et al. (2007) Biofouling and Biodegradation of Polyolefins in Ocean Waters. Polymer Degradation and Stability, 92, 1743-1752. http://dx.doi.org/10.1016/j.polymdegradstab.2007.03.029

[26] Vogt, N.B. and Kleppe, E.A. (2009) Oxo-Biodegradable Polyolefins Show Continued and Increased Thermal Oxidative Degradation after Exposure to Light. Polymer Degradation and Stability, 94, 659-663. http://dx.doi.org/10.1016/j.polymdegradstab.2009.01.002

[27] Eubeler, J.P., Bernhard, M. and Knepper, T.P. (2010) Environmental Biodegradation of Synthetic Polymers II. Biodegradation of Different Polymer Groups. TrAC Trends in Analytical Chemistry, 29, 84-100. http://dx.doi.org/10.1016/j.trac.2009.09.005

[28] O’Brine, T. and Thompson, R.C. (2010) Degradation of Plastic Carrier Bags in the Marine Environment. Marine Pollution Bulletin, 60, 2279-2283. http://dx.doi.org/10.1016/j.marpolbul.2010.08.005

[29] Setälä, O., Fleming-Lehtinen, V. and Lehtiniemi, M. (2014) Ingestion and Transfer of Microplastics in the Planktonic Food Web. Environmental Pollution, 185, 77-83. http://dx.doi.org/10.1016/j.envpol.2013.10.013

[30] Andrady, A.L. and Anthony, L.A. (2011) Microplastics in the Marine Environment. Marine Pollution Bulletin, 62, 1596-1605. http://dx.doi.org/10.1016/j.marpolbul.2011.05.030 